\title{
Differentiated instruction in teacher education: A case study of congruent teaching
}

Ilse Ruys*, Stijn Defruyt, Isabel Rots \& Antonia Aelterman

Department of Educational Studies, Ghent University Ghent, Belgium

H. Dunantlaan 2

B-9000 Ghent

Belgium

* Corresponding author. Email: Ilse.Ruys@UGent.be 


\begin{abstract}
Teachers are supposed to use forms of differentiated instruction to anticipate the differences among their students. However, the adaptation of teaching to the diversity of the group often takes place with difficulty. Teacher education is blamed for not preparing student teachers adequately for differentiated instruction. Several authors suggest that congruent teaching in teacher education might be an adequate solution to this problem.
\end{abstract}

This case study aims to investigate the (congruent) realization of differentiated instruction in teacher education using ethnographic tools. The results indicate that the observed teacher educator demonstrated limited forms of differentiation, largely without providing metacommentary. Therefore, she is not a role model on the subject of differentiated instruction in the view of student teachers. These results are discussed in depth, and form a basis for further research and suggestions for practice in teacher education.

Keywords: differentiated instruction; case study; congruent teaching; pre-service teacher education 


\section{Introduction}

During the last decades, a plea for differentiated instruction has permeated international educational research and policy. It is argued that it is the responsibility of schools to adjust to the developmental needs and level of every individual learner (Coffey, 2007; Tomlinson, 2003). Although the importance of this is almost universally recognized, its implementation in daily classroom practice seems to pose difficulty for many (beginning) teachers (Burton, 2003; Holloway, 2000; Humphrey et al., 2006). In the literature the cause of this problem is systematically placed in teacher training (Holloway, 2000; Tomlinson, 1999), which seems to be incapable of fully preparing student teachers for the hard and complex reality of teaching (Goodlad, 1990; Korthagen, 2001; Korthagen, Loughran, \& Russell 2006). According to Swennen, Korthagen, and Lunenberg (2004), a solution may be sought in congruent teaching.

This study focuses on the role of teacher education in preparing student teachers for differentiated instruction, in particular through congruent teaching. In the theoretical framework below, the central concepts and principles are clarified, followed by a case study.

\section{The demand for differentiated instruction}

The importance of adapting instruction to individual differences has been recognized since the fourth century BC (for an historical overview, see Anderson, 1995). Because of the increasing diversity and heterogeneity of the student population, educational research and policy have begun to pay renewed attention to these differences in education (Humphrey et al., 2006; Tomlinson, 2003). Often diversity and differentiated instruction are seen in 
relation to ethnicity (Banks et al., 2001) or SEN (Special Educational Needs). Inspired by Tomlinson (1999), we hold a broader view on differentiation, taking into account differences in interests, learning profiles, etc.

Tomlinson (1999) suggests that every teacher can meet the manifest diversity in educational demands of pupils by means of differentiated instruction, which is ' $a$ set of strategies that will help teachers meet each child where they are when they enter class and move them forward as far as possible on their educational path' (Levy, 2008, p. 162). These strategies cover variations in the organization of education at the school level (external differentiation) as well as in the pedagogical handling of the learning content at the classroom level (internal differentiation). Stradling and Saunders (1993) emphasize that differentiation should be thought of as a pedagogical rather than an organizational set of strategies: the purpose of differentiation is to support the learning process of children so that each individual learner in the classroom can develop his individual capabilities and limitations (Coffey, 2007; Salser, 2001; Tomlinson, 1999).

Internal differentiation is an umbrella term for a multiplicity of strategies within the classroom that pay attention to the individual capacities and educational needs of pupils, e.g., differentiation by content, level, pace, interest or structure (Adami, 2004). In external forms of differentiated instruction, differences between learners are handled in an organizational way. This can be done at the meso level by means of tracking: on the basis of certain characteristics, such as school performance and ability, pupils are grouped into separate, relatively homogeneous knots where they are offered an adjusted curriculum (Anderson, 1995; Tomlinson, 2003). In the literature, this is appositely defined as 'ability grouping' (Slavin, 1986). Typical for both types of differentiated instruction is their 
inherent connection to a specific mode of grouping. Internal differentiation tries to keep pupils with different abilities together within a heterogeneous group for as long as possible, whereas external differentiation is characterized by a homogeneous group of pupils. Nowadays it is generally assumed that 'moderate' and 'weak' learners do not benefit from homogeneous grouping (Van Houtte \& Stevens, 2009). However, for more talented students, ability grouping does show beneficial effects (Muijs \& Reynolds, 2005; Van Houtte, 2009).

\section{Teacher education under pressure}

Differentiated instruction is undoubtedly an extraordinarily useful pedagogical principle in education: 'Differentiation is widely understood to be an aspect of a teachers' professional, pedagogical competence, a shorthand for all the methods which teachers try to use within the classroom to enable each pupil to achieve the intended learning targets' (Weston, 1996 in Burton, 2003, p. 43). Although teachers acknowledge the need to address student variance, teachers often use a one-size-fits-all approach in their classrooms, disregarding students' individuality (Tomlinson, 2003; Tomlinson \& Kalbfleisch, 1998). Furthermore, beginning teachers often experience difficulties bringing differentiation into practice (Burton, 2003; Gross, 1993 in McGarvey \& Morgan, 1996; Holloway, 2000; Humphrey et al., 2006; Wertheim, 2002).

As a result, teacher education is blamed for insufficiently preparing teachers for the harsh and complex realities of daily teaching practice (Goodlad, 1990, Holloway, 2000; Korthagen et al., 2006; Tomlinson, 1999). In the literature, these difficulties are attributed to the manifest gap between theory and practice (Kessels \& Korthagen, 2001; Loughran \& Berry, 2005; Swennen, Korthagen, \& Lunenberg, 2004). The strong emphasis on academic 
knowledge in traditional teacher education has many negative implications for student teachers. First, students may experience a 'reality/transition shock' when they enter into the profession (Korthagen, 2001; Korthagen et al., 2006), which often results in extremely traditional pedagogical behaviour without much attention for the individual learner: 'Once in their own classrooms, the undertow for new teachers to "teach to the middle" is profound, both because of the complexity of teaching and because of peer pressure to conform to the "way we do school here"” (Tomlinson, 1999, p. 115). Second, baleful 'washing-out effects' can be found in the teaching practice of beginning teachers (Holloway, 2000; Korthagen, 2001).

Lortie (1975) explains the gap between educational theory and practice and the repertoire of traditional teaching by referring to 'the apprenticeship of observation,' which is analogous to 'the problem of familiarity' proposed by Geddis and Wood (1997):

"They [student teachers] have observed teaching for a considerable period of time and have formulated views about what teaching is like and how it is done. It is therefore not difficult to see how their understanding of teaching may well be caught up in a search for the familiar routines and strategies that they have experienced as students and how, at one level, their understanding of learning to teach involves simply learning those routines and strategies and applying them in practice" (Loughran, 2006, p. 105).

This implies that if we would like to stop the constant reproduction of teaching behaviour that is deemed undesirable and create a teacher education in which theory and practice are balanced (Korthagen et al., 2006), teacher educators must fully realize that 
'how we teach may speak more loudly than what we teach' (Russell, 1998, p. 2). It may also be expected that teacher educators' teaching practice can be regarded as the paragon of desirable pedagogical behaviour (Putnam \& Borko, 2000 in Lunenberg, Korthagen, \& Swennen, 2007; Tillema \& Kremer-Hayon, 2002). If change is to be established in the pedagogical behaviour of (student) teachers, the circle of teaching teachers in a traditional way has to be broken (Lunenberg \& Korthagen, 2003). Therefore, an answer to the problem of differentiated instruction in education may be found in the principle of "congruent teaching' in which a teacher educator seeks to align his own pedagogical behaviour to the behaviour he wants to encourage in student teachers.

\section{Congruent teaching as a likely solution}

Swennen, Lunenberg, and Korthagen (2008) define congruent teaching as the process of intentionally modelling desired educational practice and providing meta-commentary on it by explaining underlying pedagogical choices and linking those choices to relevant theory. Congruent teaching is almost synonymous with familiar slogans like 'teach as you preach' and 'walk your talk.'

Congruent teaching implies that a teacher educator models the pedagogical theories he introduces (Loughran \& Berry, 2005; Swennen et al., 2004). In this context, modelling is seen as demonstrating modelling behaviour in an intentional (Loughran, 2006; Lunenberg et al., 2007) or unintentional (Loughran, 2006) way, with a view to stimulating the professional learning of student teachers (Lunenberg et al., 2007).

Implicit modelling, which means that 'students experience teachers' lessons without the opportunity to talk about the reasons for enacting particular pedagogies' (Bullock, 2009, p. 292), bears the risk that teacher educators' modelling behaviour is not recognized 
as such by the students and thus the desired learning effect fails (Lunenberg et al., 2007). Based on research by Loughran and Russell (2002) and Wood and Geddis (1999), Swennen et al. (2004, p. 18) argue that 'modelling [...] is important, but it is not sufficient in itself to speak of congruent training nor it is sufficient to achieve the desired improvements in the educational training. Giving meta-commentary on the modelling behaviour is necessary' in order to facilitate the translation of the modelling behaviour to the student teachers' practices (Lunenberg et al., 2007).

As a first component of such meta-commentary, it is useful to make educational choices explicit (Lunenberg et al., 2007; Wood \& Geddis, 1999). A teacher educator explains to student teachers why he is teaching in a particular manner, he questions and makes comments on his own pedagogical behaviour, etc. (Swennen et al., 2004), in order to discourage imitation behaviour without any understanding or critical sense (Loughran, 1997).

As a second component of meta-commentary, teacher educators are expected to legitimize their pedagogical choices by linking them to and underpinning them with theoretical notions (Swennen et al., 2004). However, Bullough (1997) and Swennen et al. (2008) come to the disillusioning finding that this component of meta-commentary is rarely modelled in teacher education: 'Most of them [teacher educators] disregard publicly available theory, relying solely on personal experience, implicit theories and common sense' (Swennen et al., 2008, p. 532).

There are high hopes that congruent training will improve the pedagogical behaviour of teacher educators. Furthermore congruent training is expected to contribute to educational innovation: as teacher educators ask their students to introduce new educational principles or methods in classroom practice, they will have to give up the traditional way of 
teaching to let teacher education maintain its credibility (Kelchtermans, 2009; Swennen et al., 2004).

\section{Research design}

The theoretical framework used in this study supports individualization and differentiation. This is because of the response it can provide for the growing diversity within the student population. Moreover, teacher educators who model differentiation in their own pedagogical behaviour, and thus conform to the principles of congruent teaching, have a positive effect on the professional development of their student teachers. This theoretical basis was selected as a pretext for a case study on the realization of differentiated instruction in teacher education, taking into account the principle of congruent teaching. This study was conducted in autumn 2008 in a Flemish teacher training institute, where student teachers prepare to become primary school teachers during a three-year bachelor's program.

\section{Method}

Data for this qualitative case study were collected by using ethnographic research tools. Ethnography refers to a qualitative, interpretative research methodology that intends to 'obtain a holistic picture of the subject of study with emphasis on portraying the everyday experiences of individuals by observing and interviewing them and relevant others' (Cresswell, 1994, p. 163), with the final goal of 'grasping the native point of view' (Malinowski, 1961 [1922], p. 25). In ethnographic studies, the researcher has to intensively participate in and be part of the social life of the community that is the subject of study 
(Amit, 2000). This research technique is called 'participant observation' (Hammersley \& Atkinson, 1983).

Taking into account this principle of Malinowski, the researcher (second author) participated in all educational activities (seminars, lectures, assessment, excursions,...) that were organized as part of two courses in the second year of teacher education throughout fourteen weeks. Every (subtle or obvious) 'cultural expression,' such as actions or dialogues from over 65 hours of educational, or education-related, activities was recorded. In addition, informal interviews with Katherine, our case (see below), her colleagues and her students were conducted.

The researcher presented himself as a trainee teacher educator wanting to gain insight into the realization of differentiation in teacher education. Because of the transparency about the aim of the study, students and teacher educators were open and tolerant towards the researcher, allowing him to become a true member of the community he intended to study.

\section{Participants}

Katherine (fictitious name), the teacher educator who is responsible for the observed educational activities, is 40 years old and received a Masters degree in Educational Science in the early 90s. She worked for one decade as a pedagogue and academic researcher at a Flemish university on the topic of diversity and differentiation, making her competent in the underlying framework of its practical implementation. Afterwards, she made a wellconsidered transition to primary school teacher education in 2004, where she currently teaches pedagogical courses to student teachers in groups of 20 up to 60. At the beginning 
of the current study, Katherine and the student teachers involved were informed about the general aim of the inquiry: the researcher would observe the realization of differentiation in teacher education.

\section{Research questions}

The aim of this in-depth case study was to examine whether, how, and to what extent teacher educator Katherine is providing differentiated instruction in a 'congruent' way. In an ethnographic research approach it is rather uncommon to define specific research questions before data collection. Therefore, the following research questions were formulated during the first phases of data analysis based on the issues that 'emerged' from the data:

1) What forms of differentiated instruction can be identified in teacher education?

2) In what way is Katherine teaching in a 'congruent' way with regard to differentiated instruction?

3) Do student teachers perceive Katherine as a role model regarding differentiated instruction?

\section{Data analysis}

Following the data collection, observations and interview conversations were transcribed in raw field notes. A member check was conducted enabling Katherine to provide feedback on the accuracy of the transcriptions. The data were manually coded and analyzed in a fourstage process. 
First, the highly detailed observation reports were thoroughly read through. In this first run-through of the data, the (potentially) valuable excerpts were already clearly marked by a tag (e.g. 'student perceptions,' 'modelling,' 'meta-commentary,'...) without any interference. To attain an expansive view of the findings, in a second phase data were further organized through coding and "chunking" of meaningful text units according to similar patterns and themes (Huberman \& Miles, 1998). This was achieved by dividing the transcripts into segments, each representing a clearly distinguishable idea. Subsequently, through a process of open coding (Corbin \& Strauss, 2008), tentative categories were created. While this analysis was shaped by our theoretical understanding of differentiated instruction and congruent teaching, rather than using a pre-conceived coding scheme, we created categories based on themes evident in the data.

In a third phase, the codes produced by way of open coding were re-examined through the lens of our research questions, specifying the tentative categories and creating final themes based on the research questions and coding process. This way, data were organized into thematic categories linked to our theoretical framework and the ideas and questions that emerged during the course of ethnographic data collection. These categories were validated by the research group. In case of disagreement, consensus of final categorization was reached in a discussion between the researchers. Figure 1 presents an overview of the thematic categories emerging from the data. The final themes are illustrated by excerpts from the transcripts of field notes taken during a learning trip to the Belgian coast.

The coding and categorizing of the data allowed us to make comparisons between things in the same category and between categories (Maxwell, 2005). Hence, in a fourth 
phase, the identified patterns and themes were further interpreted, compared and discussed in research meetings in order to develop understandings relative to our research questions.

Insert Figure 1 about here

\section{Findings}

Following our research questions, below we examine three major thematic categories constructed from our data: (a) forms of differentiated instruction, (b) congruent teaching by the teacher educator, and (c) the perceptions of the student teachers. Given the limited scope of this article, not all observations are equally illustrated by excerpts from the field notes.

\section{Forms of differentiated instruction in teacher education}

The participant observation reveals that several forms of differentiation can be recognized in teacher education, both at the classroom (internal differentiation) and institutional level (external differentiation).

\section{External differentiation}

Three types of external differentiation were observed or discussed during the period of participant observation. First, flexible learning paths are offered to the student teachers, which makes it possible for them to make progress at their pace and ability. Katherine argues that this form of differentiation has a counter effect: 'Flexible learning paths were once created to meet the demands of a number of distressed students; now it is rather the rule than an exception.' During an excursion, Katherine mentioned a second external form 
of differentiation, namely the allocation of special charters to student teachers and the facilities that are therefore assigned. She referred to a student with a severe physical impairment: 'We don't expect a student who has difficulty walking to attend every lesson!' and to learning disorders as a reason for special allowances: 'A student suffering from dyslexia should always start fifteen minutes earlier to fill in his exam.' Numerous conversations between student teachers showed that there are also special charters allocated to student teachers who want to combine their study with pregnancy (parenting), a job, topclass sport or studying arts. Finally, the teacher education institute offers a voluntary screening of student teachers for the mathematics course at the start of the academic year. Those who pass this screening are excused for the lessons and examination. During an informal conversation with Katherine, she pointed at the pedagogical advantages of this form of external differentiation: 'The mathematics course can be organized for a small, homogeneous group. The students can work at their level, thus they can make much more progress. And the students who have already mastered basic math skills and passed the screening have the opportunity to invest their time and energy into courses that might be more problematic for them. It's a win-win situation!' All three types of external differentiation have strong and clear implications for teaching practice at the classroom level, e.g., more homogeneous groups of students.

\section{Internal differentiation}

What strikes one most across all field observations is the omnipresence of interest differentiation at the classroom level. Student teachers are often advised to choose a topic that appears original, creative, interesting, educational and/or relevant to their apprenticeships, etc. Another form of internal differentiation that was frequently observed 
is extended instruction. At the end of a mathematics lesson in October, Katherine intentionally repeated the instruction concerning the area of a circle for one student, while the other students store the teaching materials being used. Paraphrasing and clarifying tasks for student teachers that need more help was a more subtle form of extended instruction. This was found in nearly every lesson observed.

Three other forms of differentiation were observed only once. On the third day of observation, Katherine formed heterogeneous groups during collaborative learning: students with an individualized curriculum (APL - Accreditation of Prior Learning) were placed in a mixed group with students with a model curriculum. Within another work session, Katherine provided an assignment focused on deepening insight for students who finished early in answering the questions associated with a film on diversity and individualization in the classroom. This intervention can be regarded as a form of tempo differentiation, as well as an example of skill differentiation. A final form of internal differentiation in teacher education is the supply of two feedback sessions. Students who consider feedback desirable or necessary can submit their lesson plans digitally or face-toface for verification by Katherine the week before their apprenticeship. Students who are of the opinion that the feedback is unnecessary can give these sessions a miss.

\section{Congruent teaching by the teacher educator}

\section{Modelling behaviour}

The examples of internal differentiation show that Katherine modelled differentiated instruction in her pedagogical practice during the period of participant observation. She demonstrated more than once the purpose of her teaching actions on differentiation, stating 
explicitly when, but especially how she would differentiate between the students. After a lecture on thematic educational activities she explained spontaneously to the researcher whether or not she opted for differentiated instruction, and why.

'In a traditional lesson, like today before the break, I do not differentiate, that's just a lecture! In the second part of the lesson however, I have consciously placed the students in heterogeneous groups. I would absolutely prevent student teachers with APL working together in the same group. They have to be introduced to the rich experience base of regular students, who have much more work experience in developing lessons and themes.'

\section{Providing meta-commentary}

The field notes show that Katherine has rather limited familiarity with the provision of meta-commentary in her teaching practice. Only in three different lessons, Katherine commented on her own pedagogical behaviour related to differentiated instruction. On two occasions, Katherine stated her underlying intentions for the choices she made on differentiation. For example, in compiling heterogeneous groups she stated: 'I would like each group to adopt one of the students with APL. They do not like that, because they'd rather work with their friends, but now they have to benefit from your experience which is more extensive than theirs!' Katherine also brought her own pedagogical behaviour on differentiation into the discussion: 'Actually I have not fully taken into account your initial situation in preparing this lesson. I automatically assumed that you would know what is meant by 'the initial situation.' I should have known that I would have had to explain that term.' 
The theoretical underpinning and legitimizing of the model behaviour on differentiated instruction is even less frequently present in teacher education. Throughout the entire period of observation only one example was observed, however it was not directly related to differentiation: Katherine started with a brief overview of the structure and content of her lesson. Later on in this lesson she emphasized the importance of her modelling behaviour: '(...) Because scientific research has shown that student performance increases significantly when you tell students in advance what to do, what to expect.'

\section{The perceptions of the student teachers}

Katherine's students seem to believe that differentiation does not take place in teacher education. Only once during the observation period did a student spontaneously refer to a form of differentiated instruction in teacher education: 'The math exam [the initial screening situation], is also a form of differentiation, I think. Whoever succeeds is excused from the lessons and the exam.'

They did not recognize the other attempts at differentiated instruction by Katherine and her colleagues due to their narrow interpretation of the concept of differentiation. In interaction with the researcher students become aware of their narrow view. This is illustrated by the following excerpt:

'Some students ask for more explanation about the research. I often hear: "Differentiation? In teacher education? You will not find it! (...) Isn't it?" A student gives me a questioning look. I answer that I have already observed several forms of differentiation. I refer to the example of the assignments of the current excursion and tell them that they could choose their own theme: 
"That is an example of differentiation in response to interests." Some students look amazed: "Ah that's true, but you will not find any tempo or skill differentiation here!" I reply laconically: "And all the individual curricula in teacher education?" The girls start laughing: "Yes, we had not thought of it ... we'll leave the research to you, right?'

Katherine was also trying to broaden student teachers' view of differentiated instruction in teacher education. 'Some students need one more semester to graduate, it isn't so bad, is it? Graduating in less than three years is not possible yet - unless you have an individualized curriculum (APL) of course. That still has to be invented (laughs). You have probably not seen differentiation like that?' Many students nodded approvingly.

\section{Discussion and conclusion}

This case study, based on prolonged participant observation and informal interviews, results in a holistic view on differentiated instruction in teacher education. Different forms of differentiation are found in this study, although the variation is limited. Excluding interest differentiation and extended instruction, most forms were only observed once in the fourteen week observation period. It is striking that most of the internal forms of differentiation observed were intended to reduce the gap between the strongest and weakest performing learner and, as a consequence, hold the class group together (Gollnick, 2008). The observed external forms of differentiation, on the other hand, have the goal that all students make progress by offering them the opportunity to advance according to their intra-individual characteristics. However, one has to remember that is not unlikely that the inter-individual differences between learners in the class group will become greater in this 
case. In addition, all observed forms of differentiated instruction were focused on differences in interests, tempo, or abilities, in line with our broad definition of differentiation. As a consequence of the presence of predominantly white middle-class students in her teacher education classes, there exists a reduced focus on social and cultural diversity in Katherine's modelling behaviour. However, teacher education needs to pay attention to these aspects of diversity as well (Causey, Thomas, \& Armento, 2000).

Furthermore, our findings indicate that Katherine, who can be perceived as skilled in differentiation and individualization by her former work experience, demonstrates differentiated instruction rather restrictedly and implicitly, which makes the student teachers not perceive her as a role model for differentiated instruction. This means that giving meta-commentary is an essential aspect of the pedagogical behaviour of teacher educators. However, it became clear that meta-commentary was almost never provided by Katherine. This finding is largely compatible with the results of similar studies of Bullough (1997) and Swennen et al. (2004; 2008). As an answer to these returning results, Loughran and Berry (2005) and Loughran et al. (2008, in Berry, 2009, p. 307) suggest that the provision of meta-commentary is not evident: 'A characteristic of the 'truly expert' teacher educator is one who not only possesses a deep understanding of the 'hidden' or tacit dimensions of teaching, but also, one who can make explicit those deep understandings of practice in ways that encourage articulation by others.' However, teacher educators indicate that they do not always have sufficient knowledge of educational theories to provide meta-commentary on their pedagogical behaviour (Swennen et al., 2004). Our findings are therefore an impetus for further reflection on the possibilities of making teacher educators more familiar with and competent in providing meta-commentary. 
Katherine's restricted congruent teaching behaviour also raises questions about the responsibility of teacher trainers for integrating differentiated instruction in their own teaching practice. In the Flemish professional profile for primary school teachers (Ministry of the Flemish Government, 1998) concrete expectations are formulated regarding this pedagogical principle. Obviously teachers cannot be asked to demonstrate pedagogical behaviour that teacher educators are not demonstrating. Therefore, in line with professional standards for teacher educators in other countries, e.g. the Netherlands (Koster \& Dengerink, 2008) the association for teacher education in Flanders is working on a profile for the professional development of teacher educators. The findings of our study support the development of such a professional standard as a tool for encouraging teacher educators to reflect on their own pedagogical behaviour and to guide their own professional development.

\section{Quality of the study}

The quality of this case study was mainly ensured by the incorporation of member checks (respondent validation). Following Huberman and Miles (1998), we therefore have confidence in the interpretation of our results.

Although we draw upon ethnographic research techniques for data collection, we think a certain reserve is warranted. We do not claim to have 'done ethnography' (Wolcott, 1997). It is important to realize that our observation period was rather restricted (fourteen weeks) in view of the anthropologic tradition. In addition, we restricted our focus of study

to the pedagogical behaviour with regard to differentiation of only one teacher educator and did not take into account the broad context of teacher education. 
Because of the contextual nature of the data, the results of the case study may not simply be transferred to a broader population or other contexts (Huberman \& Miles, 1998). Furthermore, the use of ethnographic tools includes the risk of 'going native': as a result of the strong involvement in the context of the study, the researcher might lose the distance necessary for a critical view. In this study, the researcher sought a balance between 'going native' and remaining a 'cultural stranger' by taking the role of 'observer as participant' (Cresswell, 1994).

Despite these limitations, by using ethnographic data our study makes an important contribution to the research on congruent teaching in teacher education. To collect data for this study, the researcher observed for 14 weeks in teacher education. In the context of educational case studies about congruent teaching, the length of this observation period is noteworthy. Therefore, our study has a clear added value to previous research on congruent teaching, which are mainly self-studies (Loughran \& Russell, 2002; Wood \& Geddis, 1999) or cases with only one or two observations (Lunenberg et al., 2007), the latter sometimes supplemented by a stimulated recall interview (Swennen et al., 2004, 2008). Furthermore, in order to record and analyze the behaviour of a teacher educator objectively, it is recommended that data are collected by an external researcher who has knowledge of the field, since previous research indicates that teacher educators frequently assess their own behaviour inaccurately and are often unaware of the actions they perform (Swennen et al., 2004). Therefore, in our study the risk of participants behaving in a socially desirable way, which can be problematic in single non-participant observations (Huberman \& Miles, 1998), is greatly reduced since the researcher stays with them for such a long period of time 
that he is noticed less over time and the true nature of the participants' behaviour becomes visible.

Taking into account these advantages, future research on congruent teaching should incorporate these key features of the ethnographic research approach in order to obtain reliable results.

\section{Suggestions for practice}

The findings of this study may provide useful suggestions for the field of teacher education in general and the principle of congruent teaching in particular.

In the present study, Katherine was confronted with a limited amount of lesson time per course in addition to particularly large student groups. This makes it difficult to grasp the individuality of the students, which is a necessary condition for implementing and modelling forms of differentiated instruction. Structural or organizational adaptations (e.g. scaling down the student groups or scheduling a larger number of contact hours) would give more room for differentiated instruction as well as more opportunities for teacher educators to provide meta-commentary on their pedagogical behaviour.

The current changes in education, with more activity and responsibility given to the learner, bring about a different position for the teacher educator. As a result, his opportunities for congruent teaching become less pronounced and obvious. Therefore, it is useful to consider specific training, i.e., 'teaching about teaching,' for teacher educators. Congruent teaching deserves more explicit attention, including preparation on giving metacommentary. Our study shows clearly that modelling is not enough. Current initiatives, however, remain limited to one or more days of training in the context of research 
(Lunenberg et al., 2007; Swennen et al., 2008). We recommend including forms of co- or team reflection on a regular basis or establishing a professional learning community to promote teacher educators' (i.e. teachers of future teachers') skills in giving metacommentary. After all, 'it [giving meta-commentary] is complex and difficult to do and it is particularly difficult to develop alone' (Loughran, 2003 in Swennen et al., 2008, p. 532).

\section{Suggestions for further research}

Humphrey et al. (2006, p. 307) state that 'There exists little research that has explored how teachers actually understand, engage with, and respond to diversity in the classroom.' More up-to-date research on the pedagogical behaviour of teachers regarding differentiated instruction and its effectiveness is therefore needed. The influence of the international development towards more standards-based instruction has to be investigated, since standards can be an impediment to differentiated instruction. Indeed, McTighe and Brown (2005) argue that a genuine balance between educational standards and individualized approaches is both possible and necessary: 'Curriculum tells us what to teach, differentiation tells us how' (Tomlinson, 2000, p. 8).

Finally, the importance of more extensive follow-up research on congruent teaching must be stressed. So far, only limited small case studies with only one or two observations are available in the literature. In order to find more general trends in the findings, it might be useful to involve student teachers as providers of information on the pedagogical behaviour of their teacher educators. The added value of congruent teaching will only become apparent when this group recognizes and acknowledges modelling behaviour and metacommentary. This study was in line with the study of Swennen et al. (2004) in that the 
perception of student teachers was taken into account. We also recommend expanding the scale of research by studying several teacher educators for a longer period of time. As stated before, we argue for future research that takes into account the advantages of an ethnographic approach in data collection, e.g. less desirable behaviour of the participants during a lengthy period of participant observation, and the merits of an outsider perspective on the pedagogical behaviour of the participants from inside the context being studied. 


\section{References}

Adami, A.F. (2004). Enhancing students' learning through differentiated approaches to teaching and learning: a Maltese perspective. Journal of Research in Special Educational Needs, 4, (2), 91-97.

Amit, V. (2000). Constructing the Field. Ethnographic Fieldwork in the Contemporary World. London: Routledge.

Anderson, L.W. (1995). Individualized instruction. In: L.W. Anderson (Ed.). Encyclopedia of teaching and teacher education (pp.155-161). Oxford: Pergamon.

Banks, J.A., Cookson, P., Gay, G., Willis, D.H., Irvine, J.J., Nieto, S., et al. (2001). Diversity within unity: essential principles for teaching and learning in a multicultural society. Seattle: University of Washington, Centre for Multicultural Education.

Berry, A. (2009). Professional self-understanding as expertise in teaching about teaching. Teachers and Teaching: theory and practice, 15, (2), 305-318.

Bullock, S.M. (2009). Learning to think like a teacher educator: making the substantive and syntactic structures of teaching explicit through self-study. Teachers and Teaching: theory and practice, $15,(2), 291-304$.

Bullough, R.V. (1997). Practicing theory and theorizing practice in teacher education. In: J. Loughran \& T. Russell (Eds). Teaching about teaching (pp.13-31). London/Washington DC: Falmer Press.

Burton, D. (2003). Differentiation in schooling and pedagogy. In: S. Bartlett \& D. Burton (Eds.). Educational Studies: essential issues (pp.42-71). London/Thousand Oaks: SAGE. 
Causey, V.E., Thomas, C.D., \& Armento, B.J. (2000). Cultural diversity is basically a foreign term to me: the challenges of diversity for preservice teacher education. Teaching and Teacher Education, 16, 33-45.

Coffey, S. (2007). Differentiation in theory and practice. In: J. Dillon \& M. Maguire (Eds.) Becoming a teacher: issues in secondary education (third edition, pp.187-201). Berkshire: Open University Press.

Corbin, J., \& Strauss, A. (2008). Basics of qualitative research: Techniques and procedures for developing grounded theory (3rd ed.). Thousand Oaks, CA: Sage.

Geddis, A. \& Wood, E. (1997). Transforming subject matter and managing dilemmas: a case study in teacher education. Teaching and Teacher Education, 13, (6), 611-626.

Gollnick, D.M. (2008). Teacher capacity for diversity. In: M. Cochran-Smith, S. FeimanNemser, \& D.J. McIntyre (Eds). Handbook of research on teacher education: enduring questions in changing contexts (pp.249-257). London/New York: Routledge.

Goodlad, J.I. (1990). Places where teachers are taught. San Francisco: Jossey-Bass.

Hammersley, M. \& Atkinson, P. (1983). Ethnography, Principles in Practice. London/New York: Routledge.

Holloway, J.H. (2000). Preparing teachers for differentiated instruction. Educational Leadership, 58, (1), 82-83.

Huberman, A.M. \& Miles, M.B. (1998). Data management and analysis methods. In: N.K Denzin \& Y.S. Lincoln (Eds). Collecting and interpreting qualitative materials (pp.179210). Beverly Hills, CA: Sage. 
Humphrey, N., Bartolo, P., Ale, P., Calleja, C., Hofsaess, T., Janikova, V., Mol Lous, A., Vilkiene, V. \& Wetso, G.-M. (2006). Understanding and responding to diversity in the primary classroom: an international study. European Journal of Teacher Education, 29, (3), 305-318.

Kelchtermans, G. (2009). Who I am in how I teach is the message: self-understanding, vulnerability and reflection. Teachers and Teaching: theory and practice,15, (2), 257-272.

Kessels, J.P.A.M. \& Korthagen, F.A.J.(2001). The relation between theory and practice: Back to the classics. In: F.A.J. Korthagen, J.P.A.M. Kessels, B. Koster, B. Lagerwerf \& T. Wubbels (Eds). Linking Practice and Theory: The Pedagogy of Realistic Teacher Education (pp.20-31). Mahwah/New Jersey: Lawrence Erlbaum Associations.

Korthagen, F.A.J. (2001). Linking practice and theory: the pedagogy of realistic teacher education. Paper presented at the Annual Meeting of the American Educational Research Association, April 12-14, in Seattle, U.S.

Korthagen, F.A.J., Loughran, J. \& Russell, T. (2006). Developing fundamental principles for teacher education programs and practices. Teaching and Teacher Education, 22, (8), 1020-1041.

Koster, B. \& Dengerink, J.J. (2008). Professional standards for teacher educators: how to deal with complexity, ownership and function. Experiences from the Netherlands. European Journal of Teacher Education, 31, (2), 135-149.

Levy, H. M. (2008). Meeting the needs of all students through differentiated instruction: Helping every child reach and exceed standards. The Clearing House, 81, (4), 161-164. 
Lortie, D.C. (1975). Schoolteacher. Chicago: Chicago University Press.

Loughran, J. (1997). Teaching about teaching: Principles and practice. In: J. Loughran \& T. Russell (Eds.) Teaching about teaching, (pp.57-70). London/Washington DC: Falmer Press.

Loughran, J. (2006). Developing a pedagogy of teacher education. Understanding teaching and learning about teaching. London/New York: Routledge.

Loughran, J., \& Berry, A. (2005). Modelling by Teacher Educators. Teaching \& Teacher Education, 21, (2), 193-203.

Loughran, J.J. \& Russell, T. L. (2002). Improving Teacher Education Practices Through Self-study. London: Routledge/Falmer.

Lunenberg, M. \& Korthagen, F.A.J. (2003). Teacher educators and student-directed learning. Teaching \& Teacher Education, 19, (1), 29-44.

Lunenberg, M.L., Korthagen, F. \& Swennen, A. (2007). The teacher educator as a role model. Teaching and Teacher Education, 23, (5), 586-601.

Malinowski, B. (1961 [1922]). Argonauts of the Western Pacific. New York: E.P. Dutton.

Maxwell, J. A. (2005). Qualitative research design: An interactive approach (2nd ed.). Thousand Oaks, CA: Sage Publications.

McGarvey, B. \& Morgan, V. (1996). Differentiation and its problems: The views of primary teachers and curriculum support staff. Educational Studies, 22, (1), 69-82. 
McTighe, J. \& Brown, J.L. (2005). Differentiated instruction and educational standards: Is détente possible? Theory into Practice, 44, (3), 234-244.

Ministry of the Flemish Government (1998). Explanatory statement of the decree regarding the professional profile of teachers (19.12.1998) and the resolution of the Flemish Government about the basic competences of teachers (29.9.1998). Brussels: Department of Education.

Muijs, D. \& Reynolds, D. (2005). Effective teaching. Evidence and practice.

London/Thousand Oaks/New Delhi: Sage Publications.

Russell, T. (1998). Introduction to part 1: Philosophical perspectives. In: M.L. Hamilton (Ed.) Reconceptualising Teaching Practice: Self-study in Teacher Education (pp.5-6). London: Falmer Press.

Salser, M. (2001). What is individualized instruction? Portland, Oregon: Educational Research Associates, Inc.

Slavin, R.E. (1986). Ability grouping and student achievement in elementary schools: a best-evidence synthesis. Baltimore, MD: Center for Research on Elementary and Middle Schools.

Stradling, B. \& Saunders, L. (1993). Differentiation in practice: responding to the needs of all pupils. Educational Research, 35, (2), 127-137.

Swennen, A., Korthagen, F. \& Lunenberg, M. (2004). Congruent opleiden door lerarenopleiders [Congruent teaching by teacher educators]. VELON Tijdschrift voor lerarenopleiders, 25, (2), 17-18. 
Swennen, J.M.H., Lunenberg, M.L. \& Korthagen, F. (2008). Preach what you teach! Teacher educators and congruent teaching. Teachers and Teaching: Theory and Practice, 14, (6), 531-542.

Tillema, H.H. \& Kremer-Hayon, L. (2002). "Practising what we preach" - teacher educators' dilemmas in promoting self-regulated learning: a cross case comparison. Teaching and Teacher Education, 18, (5), 593-607.

Tomlinson, C.A. (1999). The differentiated classroom: Responding to the needs of all learners. Alexandria: VA: ASCD.

Tomlinson, C. (2000). Reconcilable differences: Standards-based teaching and differentiation. Educational Leadership, 58, (1), 6-11.

Tomlinson, C.A. (2003). Differentiating instruction in response to student readiness, interest, and learning profile in academically diverse classrooms: a review of literature. Journal for the Education of the Gifted, 27, (2/3), 119-145.

Tomlinson, C. \& Kalbfleisch, L. (1998). Teach me, teach my brain: A call for differentiated classrooms. Educational Leadership, 52-55.

Van Houtte, M. (2006). School type and academic culture: evidence for the differentiationpolarization theory. Journal of Curriculum Studies, 38, (3), 273-292.

Van Houtte, M. \& Stevens, P.A.J. (2009). Study involvement of academic and vocational students: Does between-school tracking sharpen the difference? American Educational Research Journal, 46, (4), 943-973. 
Wertheim, C. (2002). Efficacy beliefs, background variables, and differentiated instruction of Israeli prospective teachers. The Journal of Educational Research, 96, (1), 54-63.

Wolcott, H.F. (1997). Ethnographic research in education. In: R.M. Jaeger (ed.), Complementary methods for research in education (2 ${ }^{\text {nd }}$ edition) (pp. 155-172).

Washington: American Educational Research Association.

Wood, E. \& Geddis, A.N. (1999). Self-conscious narrative and teacher education:

Representing practice in professional course work. Teaching and Teacher Education, 15, (1), 107-119. 
Figure 1: An overview of the thematic categories used in this study, exemplified by coded field notes

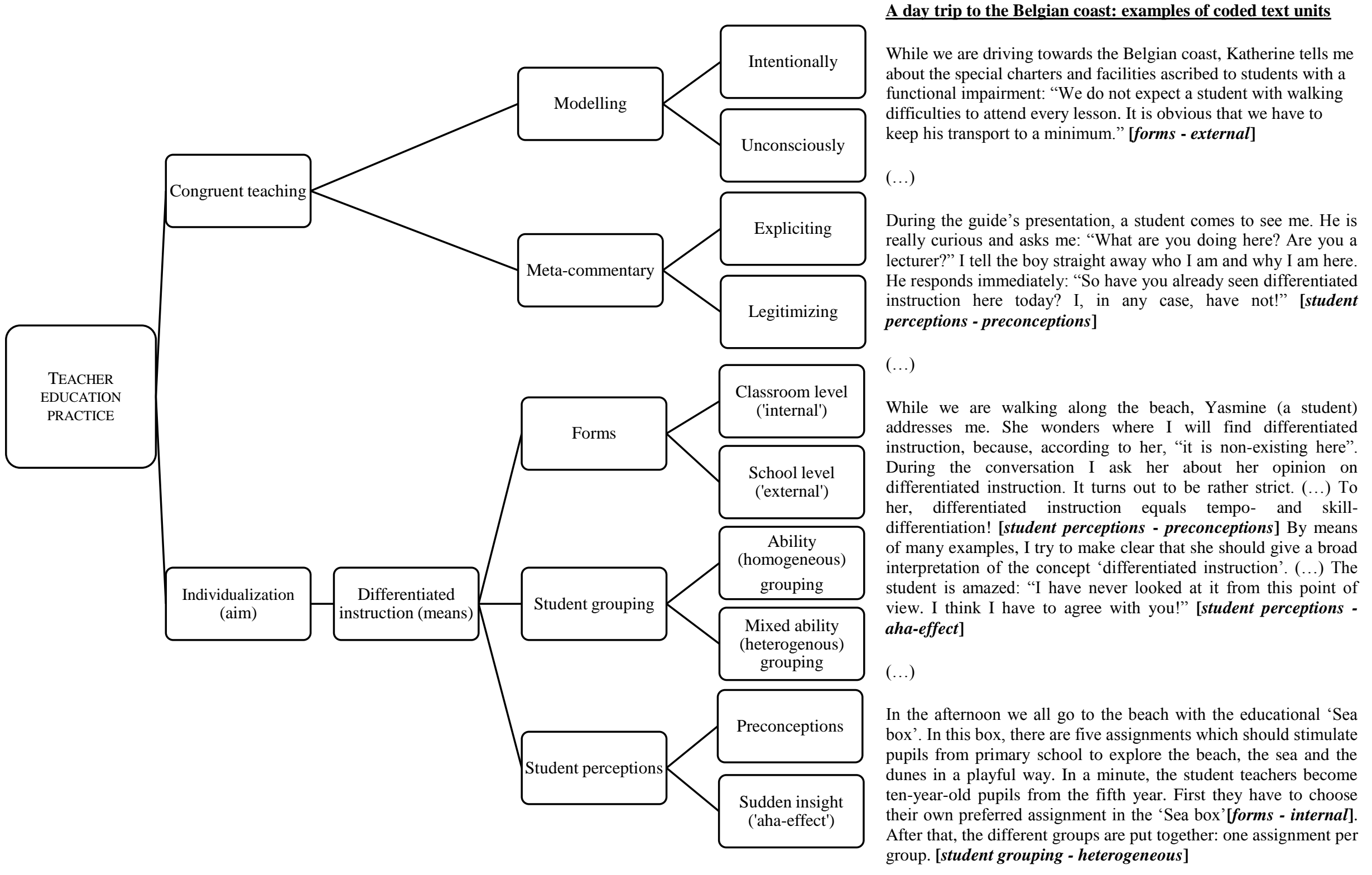


